\title{
Recorregut de recerca geològica i mineralògica per les comarques de la Ribera d'Ebre i del Baix Ebre: des de Mora la Nova a Miravet, Rasquera i al Perelló
}

Josep Maria Mata-Perelló

Joaquim Sanz Balagué

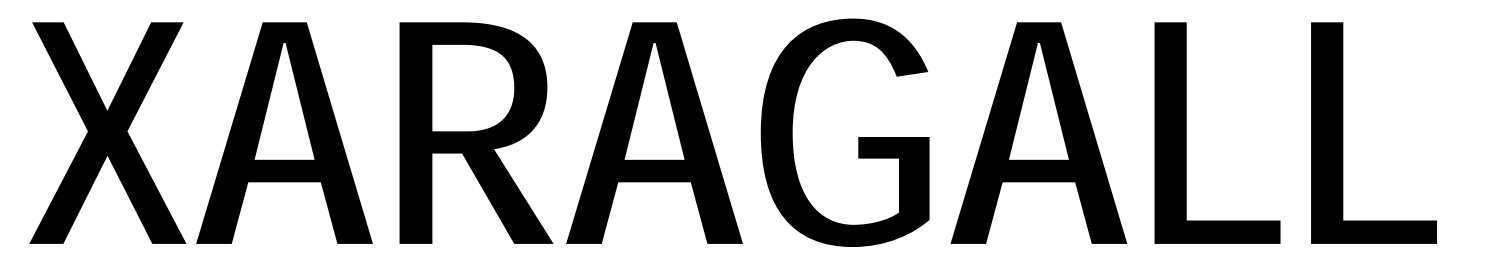

REVSTA DE CIÈNCIES DE LA CATALUNYA CENTRAL

n. 2

FEBRER 2015 


\title{
RECORREGUT DE RECERCA GEOLÒGICA I MINERALÒGICA PER LES COMARQUES DE LA RIBERA D’EBRE I DEL BAIX EBRE: DES DE MORA LA NOVA A MIRAVET, RASQUERA I AL PERELLÓ
}

\author{
Josep Maria Mata-Perelló \\ Museu de geologia Valentí Masachs, Escola Politècnica Superior d'Enginyeria de Manresa \\ (EPSEM), Universitat Politècnica de Catalunya · BarcelonaTech (UPC), 08272 Manresa, Spain
}

\section{Joaquim Sanz Balagué}

Departament d'Enginyeria Minera i Recursos Naturals (EMRN), Escola Politècnica Superior d'Enginyeria de Manresa (EPSEM), Universitat Politècnica de Catalunya . BarcelonaTech (UPC), 08272 Manresa, Spain

Paraules clau: Sistema Mediterrani, Patrimoni miner

\section{Resum}

Itinerari realitzat el 12 d'abril de 2014. En aquesta ocasió, el recorregut de l'itinerari discorrerà, en la seva quasi totalitat pel Sistema Mediterrani (i més concretament per la seva sots-unitat més interna, la Serralada Prelitoral Catalana). Així, discorrerà pràcticament per aquesta sotsunitat geològica, entre les localitats de Rasquera (Ribera d'Ebre) i del Perelló (de la del Baix Ebre). Tot i així, al primer tram del recorregut, entre Mora d'Ebre i Rasquera (dintre de la comarca de la Ribera d'Ebre), el recorregut transitarà per una altra sots-unitat del Sistema Mediterrani, concretament per la Depressió de Mora.

Així doncs, el recorregut de l'itinerari s'iniciarà a la Depressió de Mora, per la qual es circularà, molt breument, entre les localitats de Mora d'Ebre, Miravet i Rasquera, dintre de la comarca de la Ribera d'Ebre. Tot i així, en bona part d'aquest recorregut, ja es circularà també per les immediacions de la Serralada Prelitoral Catalana. A partir de Rasquera i fins a la fi del recorregut al Perelló, ja es circularà exclusivament per la Serralada Prelitoral Catalana.

Per altra banda, el recorregut s'iniciarà a la localitat de Mora d'Ebre, dintre de la comarca de la Ribera d'Ebre. Per ella es circularà fins a Rasquera, tot i que en fer la fillola de Benifallet, s'haurà penetrat momentàniament a I Baix Ebre. Més endavant, en arribar al Perelló es penetrarà definitivament a la comarca del Baix Ebre. 


\section{Objectius fonamentals}

En realitzar el següent itinerari, s'intentaran assolir els següents objectius fonamentalment, d'acord amb el sentit de la marxa del mateix.:

1. Estudi i descripció, si s'escau, dels materials terciaris eocènics i oligocènics, els quals reblen la Depressió de Mora, situada en les dos branques en que bifurca la Serralada Prelitoral Catalana. Aquesta depressió la trobarem a l'inici del recorregut del present itinerari, entre les localitats de Mora d'Ebre, Miravet i Rasquera, dintre de la Ribera d'Ebre.

2. Estudi i observació dels materials mesozoics (representat per tots els seus trams, segons els indrets), els quals formen part de la Serralada Prelitoral Catalana. Aquests materials els trobarem a la major part del recorregut de l'itinerari, entre Rasquera (on predominen el Triàsic i el Juràssic) i el Perelló (on ho fan els materials del Juràssic i els del Cretàcic).

3. Estudi de les relacions existents entre les dues unitats geològiques acabades d'esmentar, entre la Depressió de Mora i la Serralada Prelitoral Catalana; i també entre les dues branques en les quals es subdivideix aquesta darrera; així com amb la Depressió de Mora, situada entre elles. Al respecte de les dues branques de la Serralada Prelitoral Catalana, cal dir que una petita part del recorregut, entre les poblacions de Rasquera i el Perelló, el recorregut incidirà molt breument per la Branca Interna de la Serralada Prelitoral Catalana, i més concretament pel denominat Bloc de Cardó. En canvi, tota la resta del recorregut transitarà per la serralada pròpiament dita.

4. Estudi, si s'escau, d'algunes mineralitzacions situades entre els materials mesozoics de la Serralada Prelitoral Catalana. Entre aquestes, farem esment de les següents, d'acord amb el recorregut de l’itinerari.

4A) de les mineralitzacions evaporítiques guixoses, que veurem entre els afloraments dels materials triàsics del Keuper, prop de Benifallet (Baix Ebre) i de Rasquera (a la Ribera d'Ebre).

4B) de les mineralitzacions ferruginoses associades a "Hard-grounds". Aquestes es troben localitzades al Perelló (Baix Ebre), entre les calcàries del Juràssic.

5. Observació de les explotacions, relacionades amb les mineralitzacions, que anirem veien al llarg del recorregut; i en especial de les anteriors.

6. Observació i valorització de diferents aspectes relacionats amb el Patrimoni Geològic i Miner, que es vagin trobant al llarg del recorregut.

7. Observació de l'impacte produït per les explotacions anteriors (i també per les vies de comunicació o altres actuacions antròpiques) sobre el Medi Natural i sobre el Medi Ambient. Al mateix temps, s'intentarà observar el grau de restauració que s'ha produït en elles. 


\section{Antecedents}

Tret de dos antecedents nostres (Mata Perelló, 1998c, 1998d), no tenim coneixement de l'existència de cap altre antecedent bibliogràfic de caire total, en relació amb el recorregut d'aquest itinerari. Tot i així, cal parlar d'un altres recorreguts molt semblants, els quals discorren per una ruta molt similar a la present. Es tracta de Mata Perelló (2000 i 2007). Tanmateix, cal parlar dels treballs de Mata Perelló i Epuny (2000) i Mata Perelló i Ferrer (2000). Tot i així, existeixen diversos antecedents parcials, corresponents a trams del mateix. Entre aquests, farem esment d'alguns antecedents nostres, pel que fa als itineraris geològics i mineralògics, que discorren per aquestes terres, relatius als darrers anys: Mata Perelló (1996, 1997, 1998a i 1998b).

Pel que fa a l'estudi de les mineralitzacions situades al llarg del recorregut, farem esment d'un altre treball nostre, Mata Perelló (1991), relatiu al conjunt de les mineralitzacions situades arreu de Catalunya. També farem esment de la recent publicació de I'IGME (1993), relativa al full mineralogenètic de Tarragona.

I, pel que fa a l'estructura geològica dels indrets pels quals discorrerà el recorregut de l'itinerari, farem esment de dos treballs generals, relatius al conjunt dels Països Catalans: Guimerà et altri (1992), i Riba et altri (1976). En aquest aspecte, també farem esment de les publicacions de I'IGME (1978a, 1978b, 1978c, 1978d i 1986), relatius a les contrades per les quals discorrerà el recorregut d'aquest itinerari.

Tots aquests treballs esmentats, figuraran (per ordre alfabètic) a l'apartat dedicat a les REFERĖNCIES BIBLIOGRÀFIQUES, al qual ens remetem.

\section{Recorregut de l'itinerari}

El recorregut d'aquest itinerari comença a la població de Mora la Nova, dintre de la comarca de la Ribera d'Ebre, per on es realitzarà la primera aturada, si s'escau. Tot seguit, el recorregut es dirigirà cap a Ginestar i cap a les immediacions de Miravet. En aquest tram es faran noves aturades.

Posteriorment, el recorregut continuarà per la carretera $C-230$, fins arribar al trencall de Rasquera, continuant per la carretera fins superar el límit comarcal. En entrar al terme de Benifallet, es farà una nova i llarga aturada, amb diversos punts d'observació. Aquestes aturades es faran a la bora de la C-230.

Després, es tornarà endarrere, fins arribar al trencall d'on surt la carretera TV-3022, per on anirem cap a Rasquera. Des d'aquí, cal fer una altra fillola, per la carretera de Cardó, fent una nova parada al paratge de les Adous, prop de Rasquera. Després, des d'aquesta darrera població, es continuarà per la carretera local TV-3022, amb la intenció d'arribar fins al poble del Perelló. però fent una aturada abans d'arribar-hi. En aquest tram, es passarà definitivament de la comarca de la Ribera d'Ebre a la del Baix Ebre. 


\section{Advertiments previs}

Com en altres recorreguts de RECERCA GEOLÒGICA I MINERALÒGICA... si es disposa del temps suficient, poden efectuar-se passant per totes les parades i filloles. En cas contrari, recomanem reestructurar el recorregut, prescindint de les anomenades PARADES CONDICIONALS, i d'altres si s'escau.

També recomanem de cercar la informació més adient, sobre els trams a recórrer mitjançant camins de terra, o de pista. Precisament, en aquest itinerari, hi ha alguns trajectes d'aproximació cap a les mines (al Perelló, per exemple), que haurem de fer per camins de terra en irregular estat de conservació.

Per altra banda, recomanem tenir una cura extrema de la NATURA, evitant qualsevol forma d'agressió sobre ella, o de fer-n'hi un mal ús del que en ofereix la nostra mare Terra.

\section{Descripció de l'itinerari}

Com en altres itineraris, a continuació veurem una sèrie de "parades o estacions". En cada una d'elles es farà un breu comentari. Per d'altra banda, darrera del nom de d'indret (o de la parada), situarem entre parèntesi el número del Mapa Topogràfic, a escala 1:50.000, on es troba a l'indret de l'aturada.

En aquesta ocasió, utilitzarem solament quatre fulls de l'esmentat mapa topogràfic, editat per I'"Instituto Geográfico y Catastral": concretament dels següents: 471 (dit de Mora d'Ebre), 472 (dit de Reus), 497 (dit del Perelló) i finalment del 498 (dit d'Hospitalet de l'Infant).

Així doncs, la relació ordenada, de les parades que composen el recorregut d'aquest itinerari. és la següent:

\subsection{Parada 1 - CONDICIONAL. ESTACIÓ DE LA RENFE DE MORA LA NOVA, (terme municipal de Mora la Nova, comarca de la Ribera d'Ebre). (Full 471).}

En aquest indret, situat una mica al Nord de la població de Mora la Nova, és on ens caldrà iniciar el recorregut del present itinerari, al costat de l'Estació de la RENFE a Mora la Nova. En aquest indret, ens trobem situats dintre de la Depressió de Mora, i apareixen potents sediments detrítics de l'Holocè i del Pleistocè, els quals cobreixen als sediments terciaris de l'Eocè i de I'Oligocè.

Cap al Nord d'on ara som, es veuen el relleus mesozoics de les Serres de Pandòls i Cavalls; així com els relleus de la Serra de Mora (de la denominada branca externa de la Serralada Prelitoral Catalana). Al respecte, cal recordar que el riu Ebre travessa aquestes alineacions pel Pas de l'Ase.

Per altra banda, al Sud d'on ara ens trobem es veuen els relleus mesozoics del Bloc de Cardó, on ara anirem, en el recorregut d'aquest itinerari, i que forma part de l'anomenada branca interna de la Serralada Prelitoral Catalana.

Unes i altres estructures delimiten la depressió on ara estem situats, l'esmentada Depressió de Mora, situada entre la Branca Externa i la Branca Interna de I'esmentada Serralada Prelitoral Catalana del Sistema Mediterrani. 


\subsection{Parada 2 . IMMEDIACIONS DEL TRENCALL DEL PAS DE BARCA DE MIRAVET. AIGUABARREIG AMB EL BARRANC DEL COMPTE, (terme municipal de Miravet, comarca de la Ribera d'Ebre). (Full 471).}

Des de la parada anterior cal anar cap al Sud, travessant la població de Mora la Nova. I, després, tot seguint per la carretera autonòmica C-230, cal anar cap a Ginestar, per tal de continuar després cap a les immediacions del trencall que condueix cap al Pas de Barca de Miravet, sobrepassant lleugerament aquest trencall. Així, des de la parada anterior, haurem efectuat un recorregut molt proper als $12 \mathrm{Km}$.

En aquest recorregut, hem anat circulant per la Depressió de Mora, i hem trobat afloraments de materials cenozoics de I'Eocè i de l'Oligocè, fonamentalment de caràcter detrític. Per d'altra banda, molt sovint aquests materials es hem trobat recoberts per sediments detrítics del Pleistocè i de l'Holocè. Després, en arribar al volts d'on ara som, hem començat a trobar els afloraments més septentrionals dels materials mesozoics del Bloc de Cardó, els quals es fan força palesos a l'altra banda del riu. Tot i que en aquesta es troben recoberts pels terrenys quaternaris anteriorment esmentats.

Així, en mirar a l'altra banda del riu, es pot veure com Miravet es troba situat sobre una de les fractures N-S, la qual posa en contacte els materials carbonatats del Bloc de Cardó (on hi ha el Castell de Miravet) de l'altra banda del riu, i els materials cenozoics de la Depressió de Mora (on hi ha el poble). (fotografia 1).

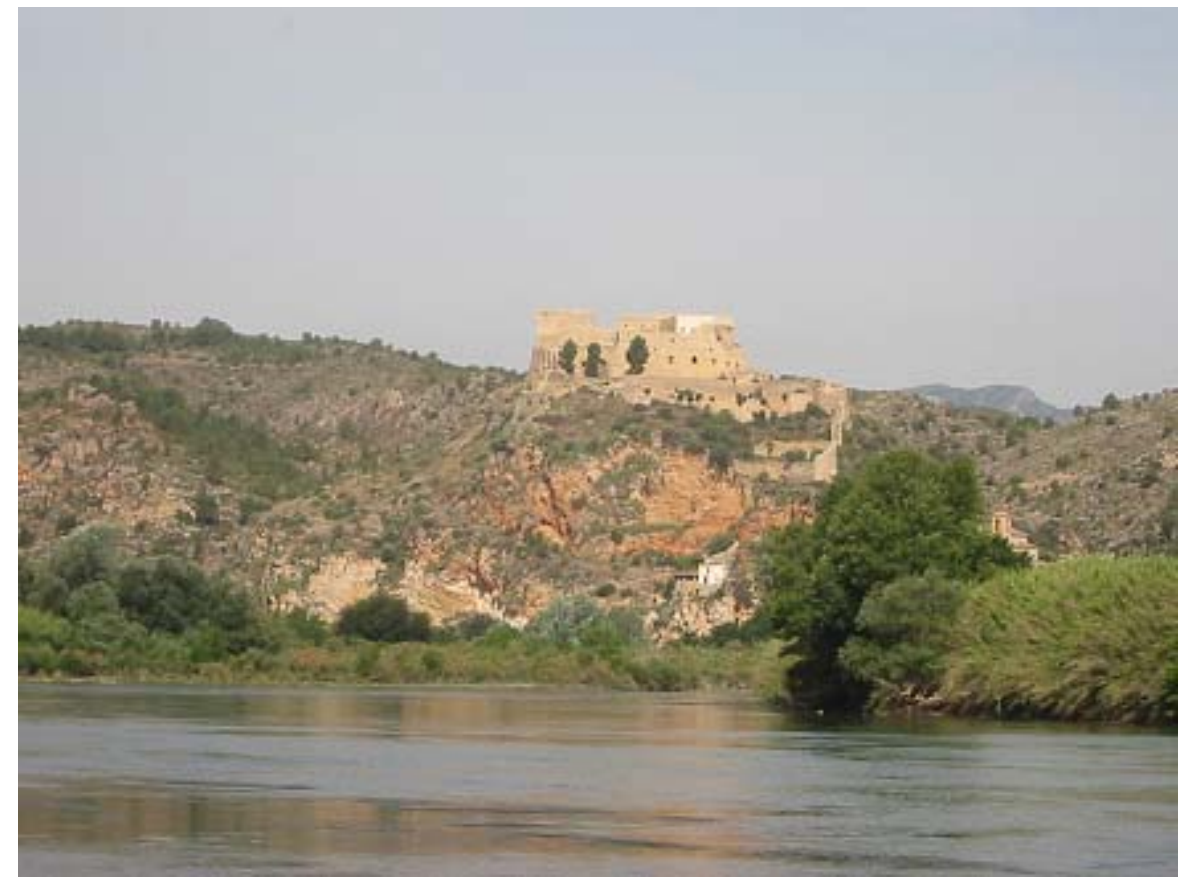

Fotografia 1. Aspecte del Castell de Miravet, des de les immediacions del Pas de Barca

També es pot veure, com el riu Ebre forma un estret en travessar els materials mesozoics del Bloc de Cardó, en deixar enrere els terrenys cenozoics de la Depressió de Mora. 


\subsection{Parada 3. Km 45'6 DE LA CARRETERA C-230, (terme municipal de Benifallet, comarca del Baix Ebre). (Full 497).}

Després de fer la parada anterior, cal continuar cap al Sud per la carretera C-230, deixant aviat enrere el trencall de Rasquera, per tal de fer una fillola, apropant-nos a les immediacions de Benifallet. Així, en arribar a l'actual Km 45'6 (prop de l'antic 31'5), caldrà fer una aturada, just després de sobrepassar el límit comarcal. Així s'haurà efectuat un recorregut proper als $7^{\prime} 5$ $\mathrm{Km}$, des de la parada anterior.

En el recorregut, fins quasi arribar al trencall de Rasquera, hem continuat amb la tònica anterior. Tot i així, poc abans de trobar-lo, ja hem trobat nivells carbonatats del Juràssic; així com nivells argilosos i lutítics del Triàsic Superior, pertanyents a la Serralada Prelitoral Catalana i més concretament del Bloc de Cardó. Hem creuat ara la falla que hem vist a la parada anterior, a Miravet.

En aquest indret es poden veure unes interessantíssimes estructures. Així baixant, es pot veure com una capa de calcàries verticalitzada descriu un doble plec, amb un pla axial vertical, i un altre lleugerament inclinat (més cap al Sud que cap al Nord), mentre que la carretera passa atrinxerada pel mig.

Seguidament, anant baixant, a uns $75 \mathrm{~m}$ de l'indret anterior, es pot veure un altre plec. Aquest segon entre nivells de calcàries i calcolutites grisenques de diferents competència, la qual cosa ha originat multitud de microplecs entre els nivells més plàstics, i fractures als més consistents.

Tanmateix, una mica més avall (a uns $100 \mathrm{~m}$ de d'anterior estructura). Es tracta d'un altre plec, que en part passa a plec-falla entre els nivells més plàstics. En aquest cas afecta als materials del triàsic, tant als del Keuper (amb argiles i guixos), que són els més plàstics, com a les calcàries i dolomies del Muschelkalk Superior. (fotografia 2 i esquema 1).

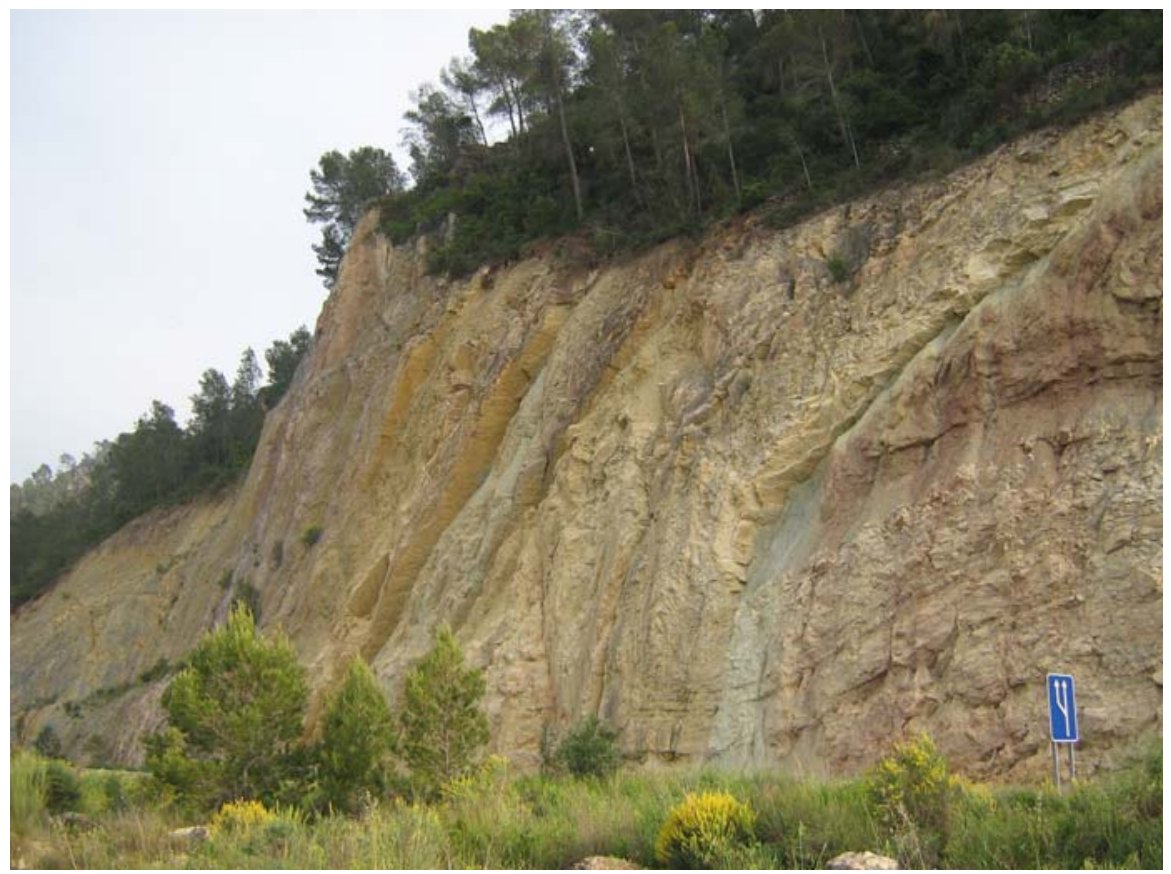

Fotografia 2. Un aspecte d'aquestes estructures, a la vora de la carretera 


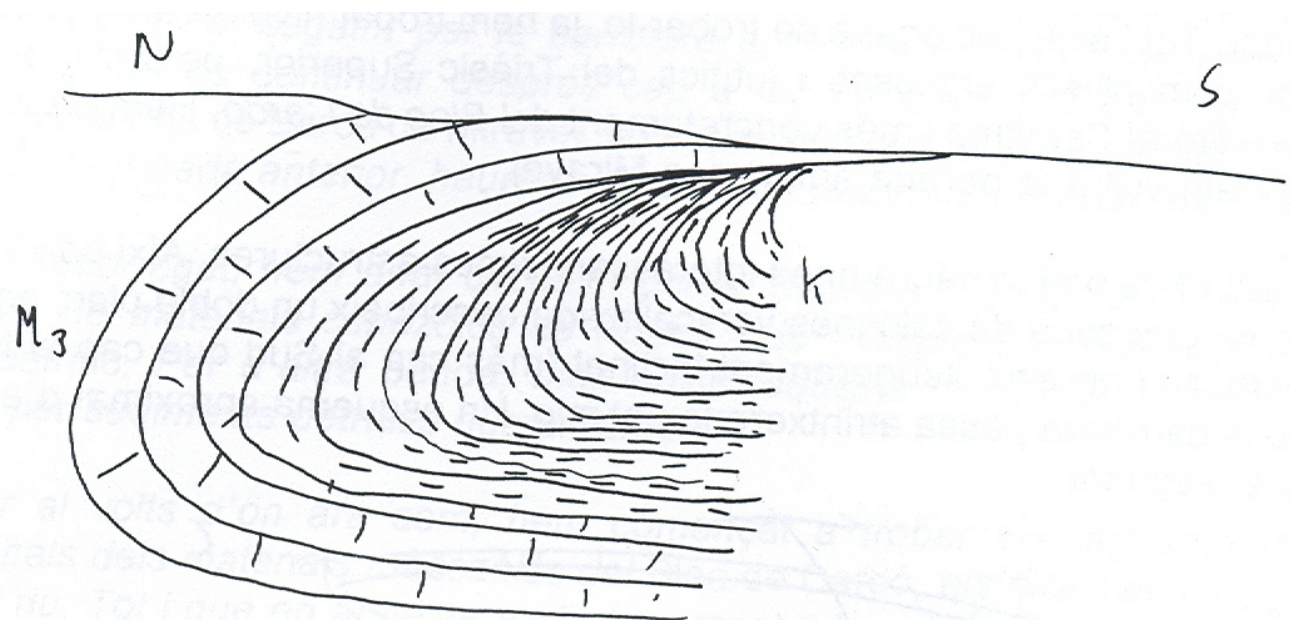

Esquema 1. Esquema aproximat del plec de la fotografia anterior

Seguidament, anant baixant, a uns $75 \mathrm{~m}$ de l'indret anterior, es pot veure un altre plec. Aquest segon entre nivells de calcàries $i$ calcolutites grisenques de diferent competència, la qual cosa ha originat multitud de microplecs entre els nivells més plàstics, i fractures als més consistents.

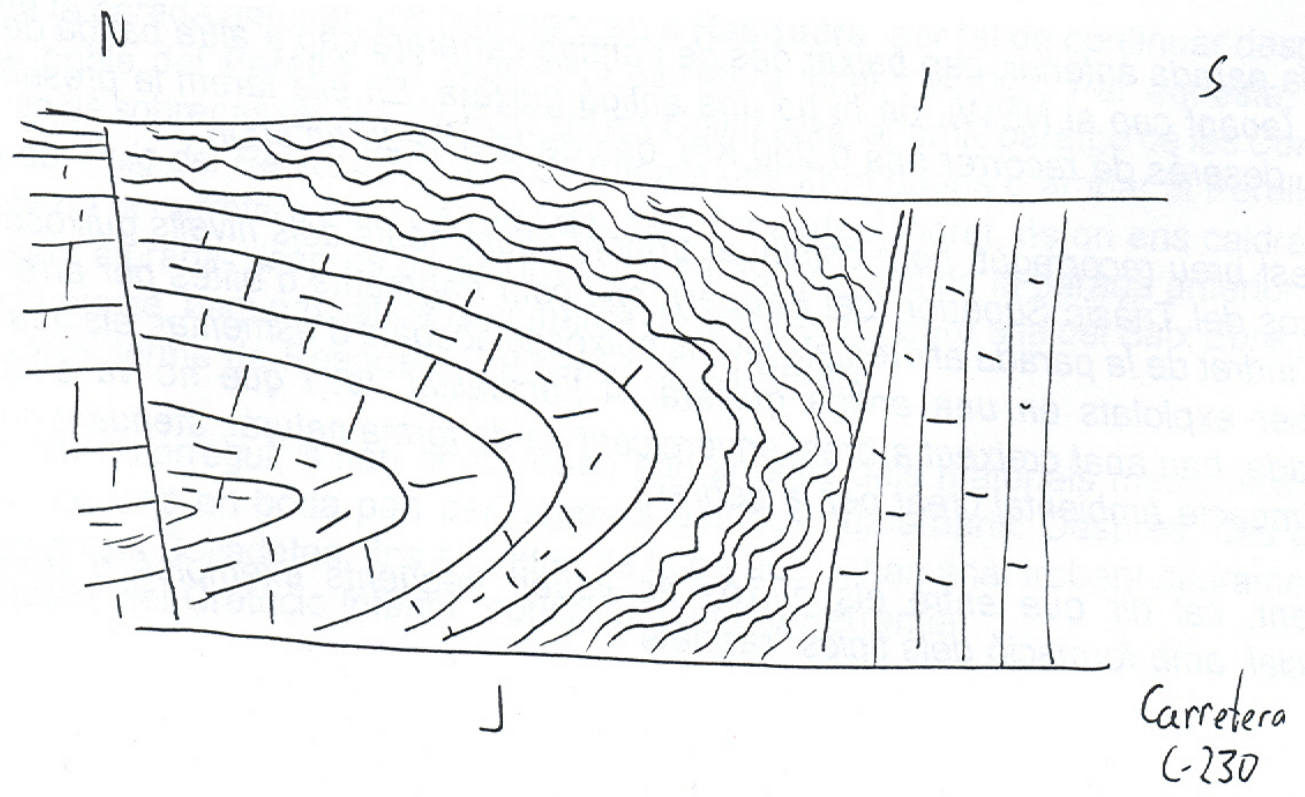

Finalment, quasi en aquest mateix lloc, a uns $100 \mathrm{~m}$ de d'anterior indret, just a un revolt de la carretera antiga, es pot veure un aflorament de ofites (diabases), les quals es troben entre els afloraments del Keuper. A aquestes diabases, es possible de veure-hi processos de saulinitització, en alterar-se els seus feldspats càlcics, passant a caolins (caolinització) i desfeta total roca superficial, transformant-la en sauló. 
També, en aquest recorregut, es pot observar com hi ha possibles perills de despreniments de blocs, per d'evident inestabilitat de les roques fracturades i replegades, la qual cosa constitueix un clar risc geològic. Aquest perill es pot atenuar mitjançant l'encolatge de les roques, i mitjançant la col-locació de xarxes. Tot i així, alhora de fer les obres de la carretera calia haverlos evitat.

\subsection{Parada 4 - CONDICIONAL. GUIXERA DE VALERI, (terme municipal de Benifallet, comarca del Baix Ebre). (Full 497).}

Des de la parada anterior, cap baixar des de l'antiga carretera cap a d'altra banda del barranc (anant cap al NNW), on hi ha una antiga guixera. En ella farem la present aturada, després de recórrer uns 0’250 Km, des de la parada anterior.

En aquest breu recorregut, hem continuat trobant afloraments dels nivells guixosos $i$ argilosos del Triàsic Superior (del Keuper), així com fragments d'ofites per arreu. Així, a l'indret de la parada afloren els nivells guixosos acabats d'esmentar, els quals van ésser explotats en una antiga guixera. A l'actualitat, tot i que no va ésser restaurada, han anat creixent arbres, embardissant-se de forma natural, atenuant una mica l'impacte ambiental creat per la pedrera. (fotografia 3).

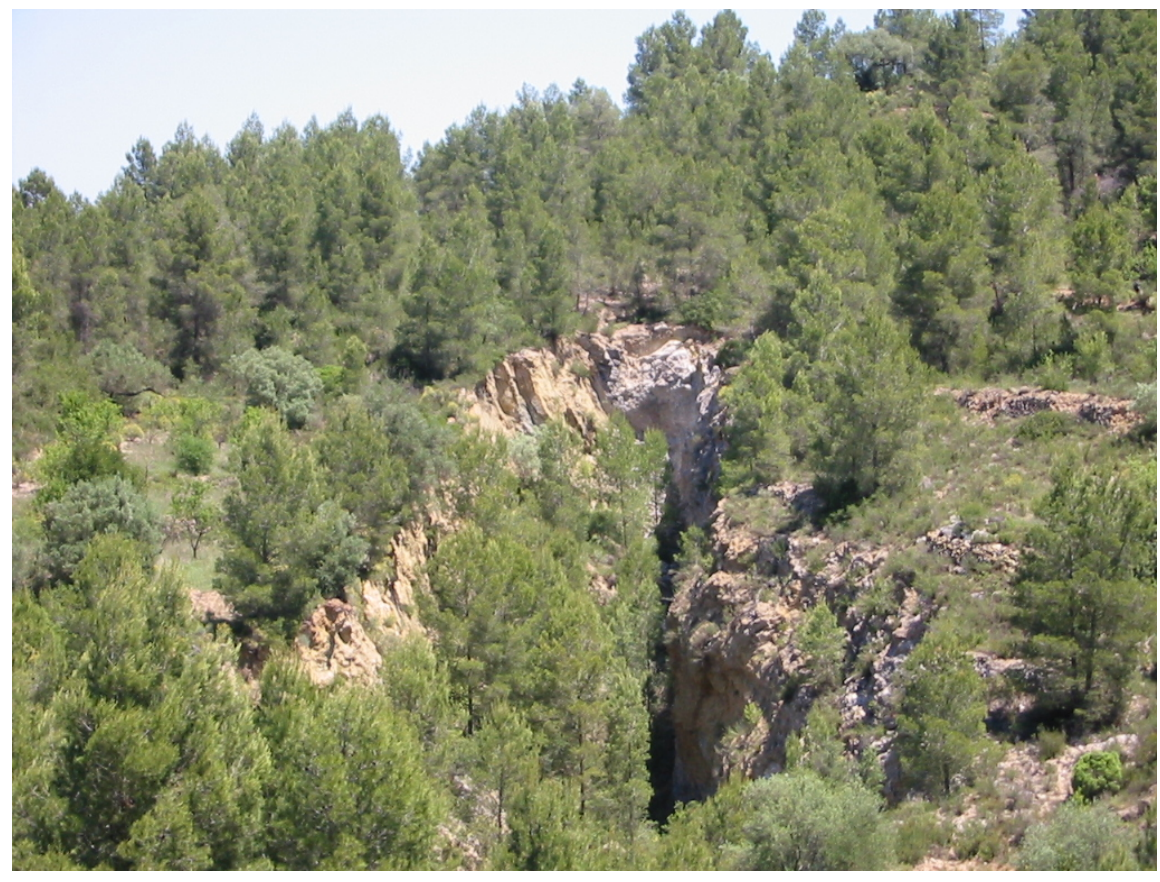

Fotografia 3. Restes de l’antiga guixera de Benifallet

Finalment, cal dir que entre els guixos es veuen freqüents exemples d'erosió superficial, amb formació dels típics "rasclets". 


\subsection{Parada 5. GUIXERES DE RASQUERA, LES ADOUS, (terme municipal de Rasquera, comarca de la Ribera d'Ebre). (Full 497).}

Des de la parada anterior, cal retornar cap al Nord, fins trobar el trencall d'on eix la carretera local TV-3022. Per ella ens caldrà anar cap a Rasquera. Després, en arribar al poble, ens cal agafar la carretera que se'n va cap a l'antic Balneari de Cardó (la TV-3021), o bé agafar el camí de les Adous. A menys de $1 \mathrm{Km}$ del poble, ens caldrà iniciar la parada, a uns $4 \mathrm{Km}$ de la parada anterior.

En aquest recorregut hem tornat a trobar els materials esmentats a la parada anterior, fins arribar al trencall de Rasquera. Després, fins a l'indret de la parada, hem anat trobant afloraments dels materials triàsics del Keuper, amb abundants guixos, els quals han estat explotats a diverses pedreres. Entre aquets nivells guixoses es troben els següents minerals: ANHIDRITA, HEMIHEDRITA i GUIX (el més abundant del tres).

Per altra banda, entre els nivells lutítics es troba la CAOLINITA i la IL·LITA. Finalment, cal dir que un altre mineral present és la CALCITA.

També es fan presents els nivells argilosos i les ofites (diabases). Hi ha un aflorament d'aquestes darreres a la cruïlla del camí del poble, amb el que baixa des de la carretera de Cardó. En aquest cas, les ofites es troben força solidificades.

Per altra banda, en aquest indret hi ha l'interessant paratge de les Adous, les quals constitueixen un punt interessant del nostre patrimoni geològic. Es tracta d'unes surgències, d'on brolla l'aigua en quantitat a les èpoques pluvioses. L'aigua procedeix d'un aqǘfer situat entre els nivells argilosos i guixosos del keuper i els carbonatats del Juràssic.

La qualitat de l'aigua és molt deficient, ja que es tracta d'aigües dures (o aigües molles, segons la varietat catalana de la zona), per la gran quantitat de bicarbonat de calci dissolta, i alhora de guix.

\subsection{Parada 6. MINA DE FERRO DE LES COMES, (terme municipal del Perelló, comarca del Baix Ebre). (Full 497).}

Des de la parada anterior, cal retornar cap a Rasquera, per tal de continuar després cap al poble del Perelló, tot seguint la carretera local TV-3022. Per aquesta, poc després de sobrepassar el Parc Eòlic de les Colladetes, a l'antic paratge de les Comes (prop del Puig del Rector). Tot això es troba a uns $2 \mathrm{Km}$ abans d'arribar al Perelló, a la dreta de la carretera i del barranc del Salt. En aquest indret, és on ens caldrà fer la present aturada, després de recórrer uns 18-19 Km, des de la parada anterior. En aquest trajecte, hem passat de la comarca de la Ribera d'Ebre a la del Baix Ebre, just al deixar el terme de Rasquera i penetrar al del Perelló, on estem ara situats.

En aquest recorregut, s'han anat trobant afloraments dels materials mesozoics del Juràssic, coberts en bona part per depòsits detrítics quaternaris del Pleistocè i de l'Holocè. Després, des dels voltants de les Colladetes, fins a l'indret de la parada, s'han anat trobant afloraments carbonatats Jdel Cretàcic Inferior, concretament del Barremià.

Tot $\mathrm{i}$ això, cal dir que en bona part del recorregut, hem estat circulant per una plana: la denominada Plana del Burgar, la qual creiem que correspon a l'antic pas de l'Ebre, el qual des de Miravet es dirigia cap al Perelló, probablement. 
A l'indret de la parada, es troba una mineralització ferruginosa associada a "hard-grond". Aquesta, s'ha desenvolupat sobre unes calcàries mesozoiques del Juràssic, recobertes pers nivells cretàcics del Barremià. Part de la mineralització ha estat remobilitzada, passant a reblir cavitats d'origen càrstic situades entre les calcàries. Així, es troben mostres, amb el òxids de ferro cimentant petits fragments de la calcària.

Entre els minerals de ferro presents, cal fer esment dels següents: GOETHITA (terrosa i lipolítica), HEMATITES (terròs) i SIDERITA (testimonial). Tanmateix, hi ha indicis de LEPIDOCROCITA i de SIDEROGEL De tots ells, el mineral de ferro més abundant és d'hematites. Tot i així, cal considerar l'abundor de la denominada LIMONITA (una roca formada fonamentalment pel primer mineral esmentat i pels dos darrers).

Finalment, cal dir que aquesta mineralització va ésser explotada, sense gaire èxit, durant el segle passat i principis d'aquest. Així, tots aquests minerals es fan força palesos a les escombreres de les diferents explotacions mineres. (fotografies 4 i 5 ).

Per altra banda, altres minerals presents, són els següents: PIROLUSITA (dendrítica), CALCITA i DOLOMITA.

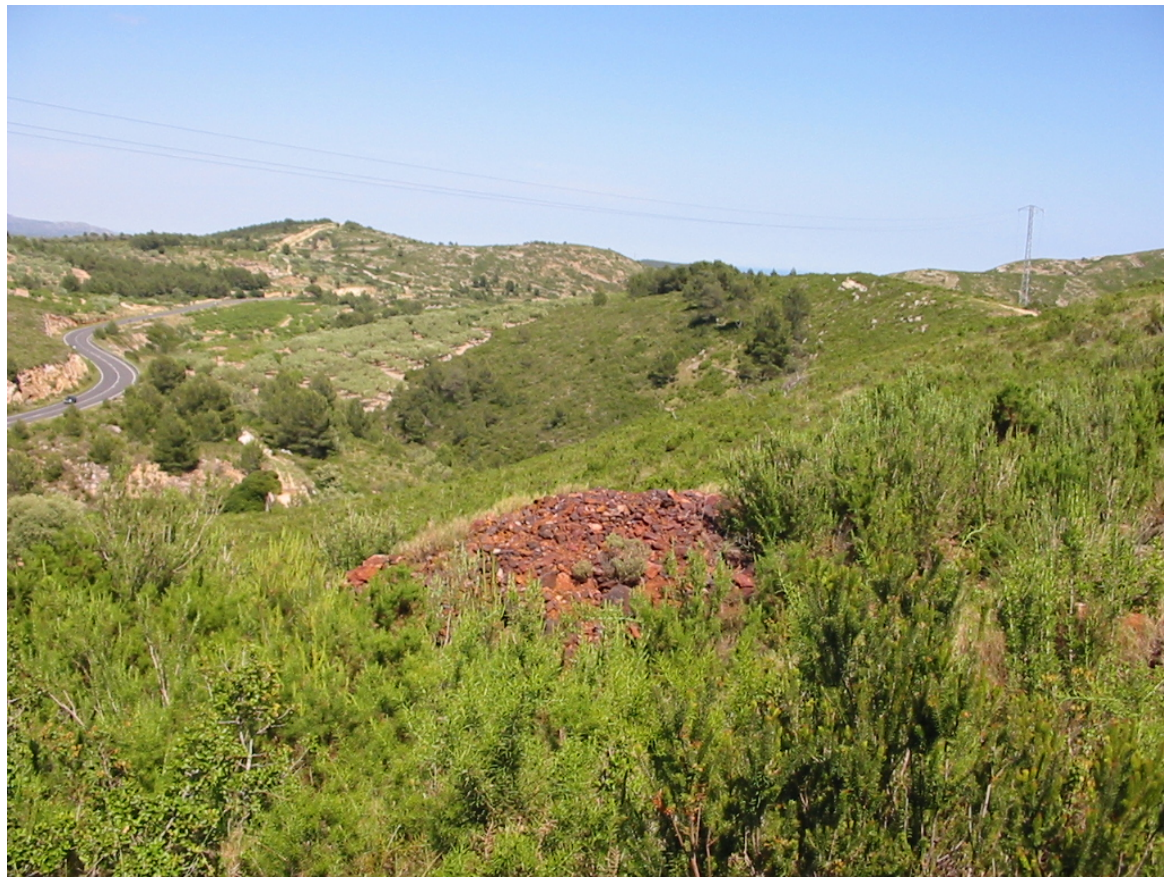

Fotografia 4. Escombrera de les antigues Mines de Ferro de les Comes. El Perelló 


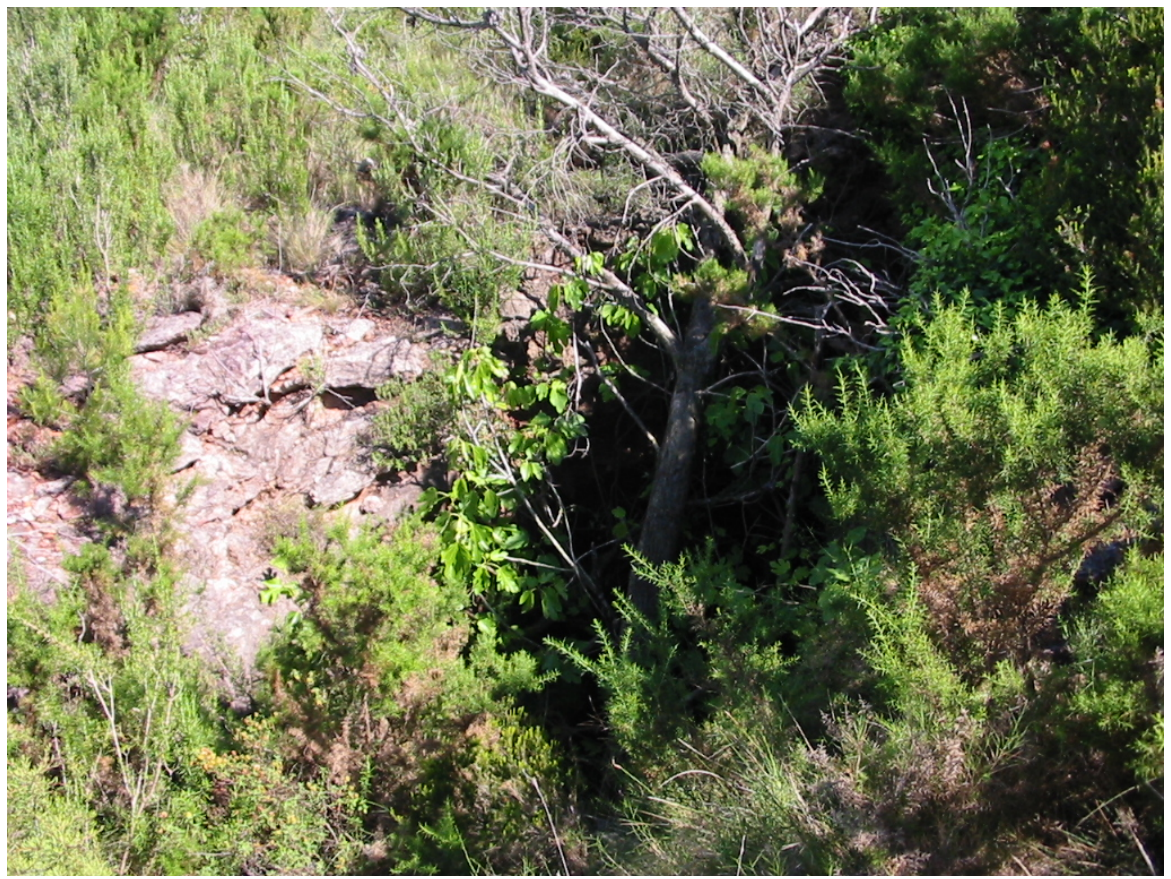

Fotografia 5. Una de les bocamines de les antigues Mines de Ferro de les Comes. El Perelló

En aquest indret finalitza el recorregut de l'itinerari

\section{Bibliografia}

GUIMERÀ, J. et altri /1992).- Geologia (II), Història Natural dels Països Catalans, Vol.2, 547 pag. Enciclopèdia Catalana, S,A, Barcelona.

IGME (1978a).- Mapa Geológico de España, a escala 1:50.000, 2a Serie. Full i memória nº 471 (Mora d’Ebre). Inst. Tecnol. GeoMinero de España. Minist. Indústria. Madrid.

IGME (1978b).- Mapa Geológico de España, a escala 1:50.000, 2a Serie. Full i memória nº 472 (Reus). Inst. Tecnol. GeoMinero de España. Minist. Indústria. Madrid.

IGME (1978c).- Mapa Geológico de España, a escala 1:50.000, $2^{\text {a }}$ Serie. Full i memória no 497 (el Perelló). Inst. Tecnol. GeoMinero de España. Minist. Indústria. Madrid.

IGME (1978d).- Mapa Geológico de España, a escala 1:50.000, 2a Serie. Full i memória nº 497 (Hospitalet de I'Infant). Inst. Tecnol. GeoMinero de España. Minist. Indústria. Madrid.

IGME (1986).- Mapa Geológico de España, a escala 1.200.000. Full i memòria, no 42 (Tarragona). Inst. Tecnol. GeoMinero de España. Minist. Indústria. Madrid.

IGME (1993).- Mapa Metalogeético de España, a escala 1.200.000. Full i memòria, $\mathrm{n}^{\circ} 42$ (Tarragona). Inst. Tecnol. GeoMinero de España. Minist. Indústria. Madrid. 
MATA-PERELLÓ, J.M. (1991).- Els Minerals de Catalunya. Institut d’Estudis Catalans. Arxius de la Secció de Ciències, T.XLVIII, 506 pag. Barcelona.

MATA-PERELLÓ, J.M. (1996).- Itinerari geologico-mineralògic pel Baix Camp i per la Ribera d’Ebre: de Mont-roig del Camp a Falset i a Tivissa. Inèdit, 12 pàg., Manresa.

MATA-PERELLÓ, J.M. (1997).- Recorregut de recerca geològica i mineralògica pel Baix Camp i per la Ribera d’Ebre: des de Montroig del Camp a Llaberia i a Tivissa Inèdit. 18 pàg. Manresa.

MATA-PERELLÓ, J.M. (1987).- Recorregut de recerca geològica i mineralògica pel Baix Camp i per la Ribera d’Ebre: des de Montbrió del Camp a Tivissa Inèdit. 18 pàg. Manresa.

MATA-PERELLÓ, J.M. (19987).- Recorregut de recerca geològica i mineralògica pel Baix Camp i per la Ribera d'Ebre: des d'Hospitalet de I'Infant a Pratdip i a Llaberia, Inèdit. 12 pàg. Manresa.

MATA-PERELLÓ, J.M. (1998c).- Recorregut de recerca geològica i mineralògica per les comarques del Baix Camp, de la Ribera d'Ebre i del Baix Ebre: des de l'Hospitalet de I'Infant al Perelló, per Pratdip i per Tivissa. Inèdit, 16 pag. Manresa.

MATA-PERELLÓ, J.M. (1998d).- Recorregut de recerca geològica i mineralògica per les comarques del Baix Camp, de la Ribera d'Ebre i del Baix Ebre: des de l'Hospitalet de I'Infant al Perelló a Tivissa i al Perelló. Inèdit, 18 pag. Manresa.

MATA-PERELLÓ, J. M. (2000).- Recorregut de recerca geològica i mineralògica per les comarques del Baix Camp, de la Ribera d’Ebre i del Baix Ebre: des de Mora la Nova al Perelló, i des de l'Hospitalet de I'Infant a Tivissa. Inèdit, 12pag. Manresa.

MATA-PERELLÓ, J. M. (2007).- Recorregut de recerca geològica i mineralògica per les comarques de la Ribera d’Ebre i del Baix Ebre: des de Mora la Nova a Rasquera, el Perelló, la Aldea i a les Salines de la Trinitat. Inèdit. 12 pàgines. Manresa.

MATA-PERELLÓ, J. M. I ESPUNY SOLANÍ, J. (2000).- Apunts per a un recorregut de recerca geològica i mineralògica per les comarques del Baix Ebre i del Montsià: des de I'Aldea a Tortosa i Ulldecona, i des d'Alcanar a Sant Carles de la Ràpita. Inèdit. 10 pag. Manresa.

MATA-PERELLÓ, J. M. I FERRER CLARIS, R. (2000).- Recorregut de recerca geològica i mineralògica per les comarques del Baix Camp, de la Ribera d'Ebre i del Baix Ebre: des de Mora la Nova a Rasquera i del Perelló a Gavadà i a Fatxes. Inèdit. 14 pag. Manresa.

RIBA, O. et altri (1976).- Geografia Física dels Països Catalans. Edit. Ketres, 254 pàgines. Barcelona. 